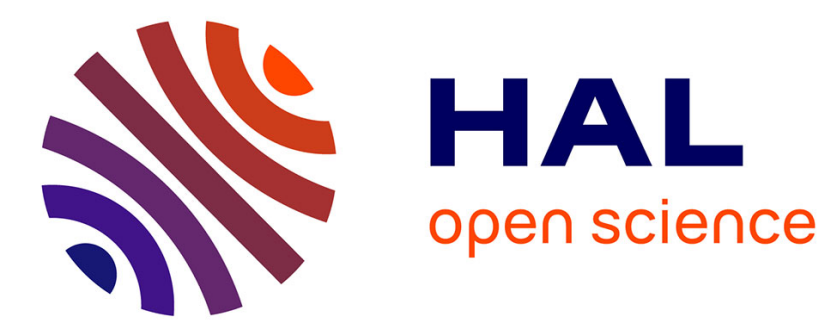

\title{
Banks risk race: A signaling explanation
}

Damien Besancenot, Radu Vranceanu

\section{- To cite this version:}

Damien Besancenot, Radu Vranceanu. Banks risk race: A signaling explanation. 2011. halshs$00424214 \mathrm{v} 2$

\section{HAL Id: halshs-00424214 \\ https://shs.hal.science/halshs-00424214v2}

Preprint submitted on 27 Apr 2011

HAL is a multi-disciplinary open access archive for the deposit and dissemination of scientific research documents, whether they are published or not. The documents may come from teaching and research institutions in France or abroad, or from public or private research centers.
L'archive ouverte pluridisciplinaire HAL, est destinée au dépôt et à la diffusion de documents scientifiques de niveau recherche, publiés ou non, émanant des établissements d'enseignement et de recherche français ou étrangers, des laboratoires publics ou privés. 
February 1, 2011

\title{
BANKS' RISK RACE: A SIGNALING EXPLANATION
}

\section{Damien Besancenot*and Radu Vranceanu ${ }^{\dagger}$}

\begin{abstract}
Many observers argue that one of the major causes of the 2007-2009 recession was the abnormal accumulation of risk by banks. This paper provides a signaling explanation for this race for risk. If banks' returns can be observed while risk cannot, the less efficient banks can hide their type by taking more risks and paying the same returns as the more efficient banks. The latter can signal themselves by taking even higher risks and delivering bigger returns. The game presents several equilibria that are all characterized by excessive risk taking as compared to the perfect information case.
\end{abstract}

Keywords: Banking sector, Risk strategy, Signaling, Imperfect information, the Great Recession. JEL Classification : G21; G32; D82.

\footnotetext{
*University Paris 13 and CEPN, 99 Avenue Jean-Baptiste Clément, 93430 Villetaneuse, France. E-mail: besancenot.damien@univ-paris13.fr

†ESSEC Business School and THEMA, 105 Av. Bernard Hirsch, 95021 Cergy, France. E-mail:
} vranceanu@essec.fr. 


\section{Introduction}

The 2007-2009 recession has been by all dimensions one of the most severe since the Great Depression (Brunnermeier, 2009). Social costs were huge, both in terms of output loss and rising unemployment (IMF, 2010). Fiscal positions of many countries were deeply undermined, with lasting consequences on growth prospects. While scholars will debate for many years about the deep causes of the crisis, a majority of experts claim that one essential determining factor was the abnormal accumulation of risk by banks (inter alia, Borio, 2008; Trichet, 2008; Diamond \& Rajan, 2009; Stiglitz, 2010; Pomfert, 2010). This observation begs the question on why, in the first place, did banks engage in what can be described as a genuine race for risk?

The answer submitted in this paper brings into the picture the asymmetric information between banks' shareholders and managers with respect to the structural risk of these financial institutions. One key feature of banks' activity is their opacity in functioning and management. As emphasized by Morgan (2002, p.874) "risks taken into the process of intermediation are hard to observe from outside the banks". Indeed, banks are traditionally very reluctant to disclose any information about their clients on both sides of their balance sheets. Furthermore, the composition of their asset portfolio is both a strategic decision and a key factor of success; no bank will eagerly disclose this information. Over the last twenty years, the complexity and opacity of banks' financial intermediation has increased dramatically, being driven essentially by a shift from the traditional "deposit and loan" model to the "orginate-to-securitize" model (Diamond \& Rajan, 2009; Stiglitz, 2010). In theory, securitization should have allowed banks to transfer most of the credit risk to a myriad of investors; in practice, it turned out that during this crisis US banks kept large amounts of high risk securities on their books; furthermore, when difficulties arose, they had to cover the risks embedded in off-balance sheet entities they had created for securitization purposes. European banks have also aggressively invested in CDOs with a hidden content in US subprime loans, that had a true risk known only to a minority of insiders.

In general, given that higher risks command higher returns, banking technology allows the manager to choose the preferred risk/return combination. As the experience of the 2007-2009 
recession has shown, banks are not equally equipped to face adversity. Newspapers extensively covered the dramatic situation of failing banks; other banks came out as unchallenged winners from the restructuring process. ${ }^{1}$ Actually, banks differ in their portfolio of activities, investment and loan opportunities, risk management systems and operating costs. Empirical literature has revealed that problem loans and cost efficiency are related measures, with banks approaching failure featuring both high ratios of problem loans and low cost efficiency (Berger \& DeYoung, 1997; DeYoung, 1997). In order to keep the model as simple as possible, in this paper we focus only on differences in cost efficiency, but the structure of the problem and the conclusions would not change much if we alternatively consider that less efficient banks have also less investment opportunities than the more efficient banks.

We assume that there are (only) two types of banks, the high cost-efficient (or "good") ones and the low cost-efficient (or "bad") ones. ${ }^{2} \quad$ A caveat is needed here: if a banks spends more resources monitoring the quality of its portfolio and is quicker to write-down unperforming assets, then these higher costs would not necessarily be representative of a bad management (Boot \& Marinc, 2006). In our setup, cost efficiency is a basic measure of wasted resources in a static perspective. Thus, a less efficient bank can deliver the same returns as a highly-efficient bank only if it takes more risks on its balance sheet. The bank-specific risk/return relationship is introduced in a very stylized way, inspired by the traditional model by Markovitz (1952). More precisely, the bank is represented as a portfolio manager, investing shareholders wealth in a convex combination between the riskless asset and a portfolio of risky assets.

Building on this simplified bank model, we analyze banks' risk/return strategies within the framework of a classical signaling game (Spence, 1973, 2002; Riley, 1975) that opposes banks' managers to shareholders. In a perfect information world, all investors would flee the less efficient banks to join the most efficient ones, and the former type of bank would be pulled out of the market. However, if returns can be observed by private investors but risk cannot, then less efficient banks

\footnotetext{
1 The dramatic fall of Lehman Brothers, or the massive support of the respective governements to rescue Citigroup, UBS, Royal Bank of Scotland, Northern Rock, Hypo Real Estate or Dexia, etc. can be weighted against rather successful stories of Barclays, HSBC, Nomura, Santander, Goldman Sachs, JP Morgan Chase, and so on.

2 Empirical studies show that over a long period, the average bank incurs costs 20 to $25 \%$ higher than costs at the most efficient banks (DeYoung, 1997). Haslem et al. (1999) use data envelopment analysis to show that about $20 \%$ of the large US bank were inefficient in 1992 .
} 
would survive if they manage to conceal their type. They can do so by increasing the amount of risk in order to deliver the same returns as the high efficient banks. In equilibrium, the less efficient banks take too much risks.

Another set of strategies can be obtained if the regulator can set an upper limit on the amount of risk that banks can take, but, to protect banks' business model, does not publicly disclose the bank specific information. In general, regulators get information on bank risk exposure through on-site and off-site examinations or staff members working within the banks. Their task is not an easy one given limitations on disclosure and the underlying exposure in banks' trading books, particularly when complex instruments are in question. After 2008, regulators carried out time-consuming stress tests that measure a bank's resilience to simulated additional macroeconomic shocks. In May 2009, the US Federal Reserve System made public the methodology and results of these tests for each of the nineteen large banks subject to these checks, while the European regulators decided to keep the bank-specific information secret and disclose only aggregate information. ${ }^{3}$ So in the European context, the regulator's information was private knowledge. Some prudential ratios might also be communicated only to the regulator, without being publicly disclosed. If such an upper bound on risk exists, and this limit is known by banks only (and the regulator), good banks can signal themselves by increasing returns (and risk) up to the point where bad banks cannot follow them. If not all good banks undertake the costly "super-signaling" strategy, then bad banks can further survive by taking excessive amounts of risk.

This extended game presents several types of equilibria, depending on the proportion of good banks and the gap in operating costs. The main contribution of the paper is to emphasize that, under imperfect information, in any of these equilibria at least some banks have no other optimal choice than to hold on their balance sheet more risk than in a perfect information set-up. Furthermore, for some parameter values, we get a typical configuration of multiple equilibria; which one of them actually materializes ultimately depends on investors' beliefs. In a multiple equilibria setting, the economic system is prone to extreme instability.

\footnotetext{
3 In June 2010, Spain decided to make public the results of stress tests performed on national banks. Despite some protest on behalf of Germany, the other European leaders agreed on making public the stress tests carried out by the Committee of European Bank Supervisors.
} 
Our simplified bank model does not allow to bring into the picture the capital-to-asset ratio, an indicator traditionally used to assess a bank financial health. ${ }^{4}$ After the crisis, policymakers took significant steps with the aim of capping the amount of risk that banks can take. One important decision adopted by the Basel Committee on Banking Supervision on September 12, 2010 was to increase the minimum common equity requirement ratio to $7 \%$, as compared to $2 \%$ before the crisis (banks have time until 2019 to comply with this new target). We would notice that the extensive literature on the relationship between capital requirements and risk taking is somehow inconclusive; some authors have even suggested that higher capital buffers may actually facilitate higher risk-taking (Kahane, 1977; Koehn \& Santomero, 1980; see also the survey by VanHoose, 2007). Since a high capital-to-assets ratio is both observable and involves an opportunity cost for the bank, this indicator could also be used for signaling purposes. If weak banks can set aside as much capital as strong banks (and take higher risks), then strong banks might be able to signal themselves by rising the capital ratio well above the legal minimum, to the point where weak banks cannot follow them. This alternative approach would provide an interesting path for further research.

The paper is organized as follows. The next section introduces our main assumptions. Section 3 analyzes the equilibria of the game. Section 4 presents our conclusions.

\section{Main assumptions}

The model is cast as a game between banks' managers and shareholders under imperfect information of the latter about the structure of the asset portfolio of the bank. The banking sector is made up of publicly listed banks, that take deposits and issue debt in order to grant loans and buy financial assets. If the bank has access to a risk-free asset and to a portfolio of risky assets and loans, the manager can pick any combination of risk/return along the capital market line, a tangent to the efficient frontier (Markowitz, 1952). A higher return can be obtained only if the bank takes more risks (by investing more in the efficient portfolio of risky assets and loans).

Denoting the net return by $R$ and the amount of risk by $v$, this typical trade-off between risk

\footnotetext{
4 Implicitly the model assumes that good and bad banks have the same capital and assets, and differ only in operating costs.
} 
and return for a bank of type $i$ can be written:

$$
R^{i}(v)=R_{0}+\theta v-c^{i},
$$

where $R_{0}>0$ is the interest rate of the risk-free asset, $\theta>0$ is the slope of the capital market line and $c^{i}$ stands for the bank-specific operating cost. ${ }^{5}$ The inverse function, indicating the risk needed to achieve a given return for a bank with operating cost $c^{i}$ is also of interest for further developments:

$$
v^{i}(R)=\theta^{-1}\left[R-R_{0}+c^{i}\right]
$$

We assume that, depending on the quality of their management, banks differ in their operating costs. $^{6} \quad$ To keep the model as simple as possible, we assume that banks can be of two types: "good" banks (of type $g$ ) with a low operating $\operatorname{cost} c^{g}$ that can be normalized to zero without loss of generality and "bad" banks (of type $b$ ) with a high operating cost $c^{b}=c>0$. In Figure 1, we represent the capital market lines of such a good and bad bank. It can be noticed that in order to provide shareholders with the same net return, bad banks must take riskier bets, that is $v^{b}(R)>v^{g}(R), \forall R>R_{0}$.

Let $q$ be the proportion of good banks in the total population of banks, $1-q$ being the proportion of bad banks. This distribution of banks is common knowledge.

In a general form, we represent the utility of the representative risk-averse shareholder's by a quasiconcave function $U(R, v)$, with $\partial U(,) / \partial R>0, \partial U(,) / \partial v<0$. Resulting indifference curves are convex.

Shareholders agree to pay the bank's manager a compensation that is proportional to their perceived utility, or $W=\gamma E[U(R, v)]$, where $E[-]$ is the expectations operator, ${ }^{7}$ the compensation factor $\gamma$ is not essential, so we normalize it to 1 .

Under these assumptions, in a perfect information set-up, a manager running a good bank

\footnotetext{
5 Financial literature focuses on return variance (denoted often by $\sigma^{2}$ ) as a proxy for risk. The risk considered in this text is of the nature of an extreme event. The impact of such event on the firm cannot be directly inferred from the observed return variance.

6 The structure of the problem and the solution would not change if, instead of different operating costs, we assume that banks differ in their investment opportunities (thus, the Markovitz frontier would be broader for the stronger bank, and the slope of its capital market line would be steeper than for the weaker bank).

7 These expectations will be determined over the set of beliefs about the type of bank given the return strategy.
} 


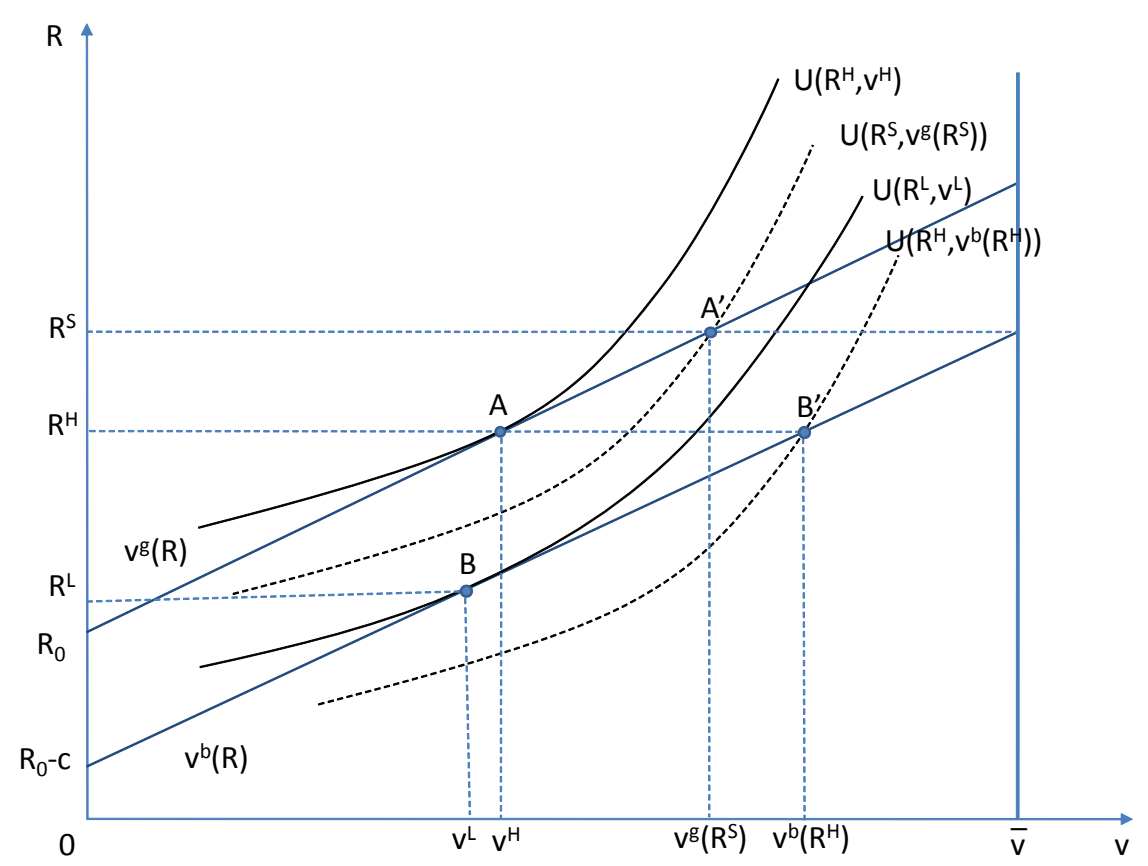

Figure 1: Return strategies, risk and utilities

would simply choose the bundle $\left(R^{H}, v^{H}\right)$ that maximizes his income given the bank's capital market line, such as indicated at point A in Figure 1.

Notice that the manager of a bad bank would prefer the bundle $\left(R^{L}, v^{L}\right)$, at point $\mathrm{B}$ in the same figure. Yet, given that shareholders' satisfaction is higher for good banks than for bad banks, no investor would hold the bad bank stocks: therefore less efficient banks cannot survive in this perfect information world.

However, the assumption of perfect information is not very realistic given that a bank's risk exposure is a very complex commodity. As noticed in the Introduction, it is very difficult for outsiders, even for expert ones, to evaluate the full amount of risk taken by a bank. Building on these basic fact, we further assume that the level of risk exposure of a given bank is private information to its manager, while the stock return is public information. In this context the set of strategies of the banks is more sophisticated:

- For bad banks, like in the perfect information set-up, the strategy of playing $R^{L}$ is never optimal since it reveals the type of the bank and all the shareholders would leave it. At difference with the perfect information case, in the imperfect information environment a bad 
bank can survive if it manages to conceal its type. It can reach this outcome by increasing the riskiness of its portfolio such as to deliver the return $R^{H}$, i.e. the perfect information return of the good bank (at point B' in Figure 1).

- Good banks can play their perfect information optimal strategy $R^{H}$ as well. However, if good banks want to make sure that no bad bank has an incentive to imitate them, they should pay a sufficiently high return that a bad bank cannot deliver it. In order to analyze the broadest set of equilibria, we consider that regulators can set an upper limit on the total risk allowed to be taken by any bank, a limit denoted by $\bar{v}$ (the vertical line on Figure 1). This upper limit on risk is known by banks. We assume that shareholders no not have the same ability to measure risk as the regulator. ${ }^{8}$ Then, if a bank pays a return slightly above $R^{S}$, defined by:

$$
R^{S}=R_{0}+\theta \bar{v}-c
$$

it unambiguously signals itself as a good bank, given that bad banks cannot further increase risk such as to copy them. $R^{S}$ is thus the second return strategy of the good bank.

Turning now to the manager's payoff, we argued that if investors perceive that a bank is of the bad type, this bank leaves the market and the compensation of the manager becomes zero. So, a positive compensation for the manager can be defined only for banks that stay on the market (i.e., those that are not been perceived as being bad banks). Denoting by $\operatorname{Pr}\left[i \mid R^{j}\right]$ the probability shareholders assign to the event that a bank is of the type $i$, with $i \in\{b, g\}$, if the return strategy is $R^{j}$, with $j \in\{L, H, S\}$, the manager's payoff can be written:

$$
W\left(R^{j}\right)=\left\{\begin{array}{l}
0, \text { if } \operatorname{Pr}\left[b \mid R^{j}\right]=1 \\
\operatorname{Pr}\left[g \mid R^{j}\right] U\left(R^{j}, v^{g}\left(R^{j}\right)\right)+\operatorname{Pr}\left[b \mid R^{j}\right] U\left(R^{j}, v^{b}\left(R^{j}\right)\right), \text { if } \operatorname{Pr}\left[b \mid R^{j}\right] \in[0,1[
\end{array}\right.
$$

Notice that return strategies $R^{S}$ and $R^{L}$ reveal perfectly a bank's type. Thus $W\left(R^{S}\right)=U\left(R^{S}, v^{g}\left(R^{S}\right)\right)$ and $W\left(R^{L}\right)=0$.

Figure 2 presents the decision tree.

The typical sequence of decisions goes like this:

\footnotetext{
${ }^{8}$ As mentioned in the Introduction, this situation is characteristic for instance of the European banking landscape between June 2009 and June 2010.
} 


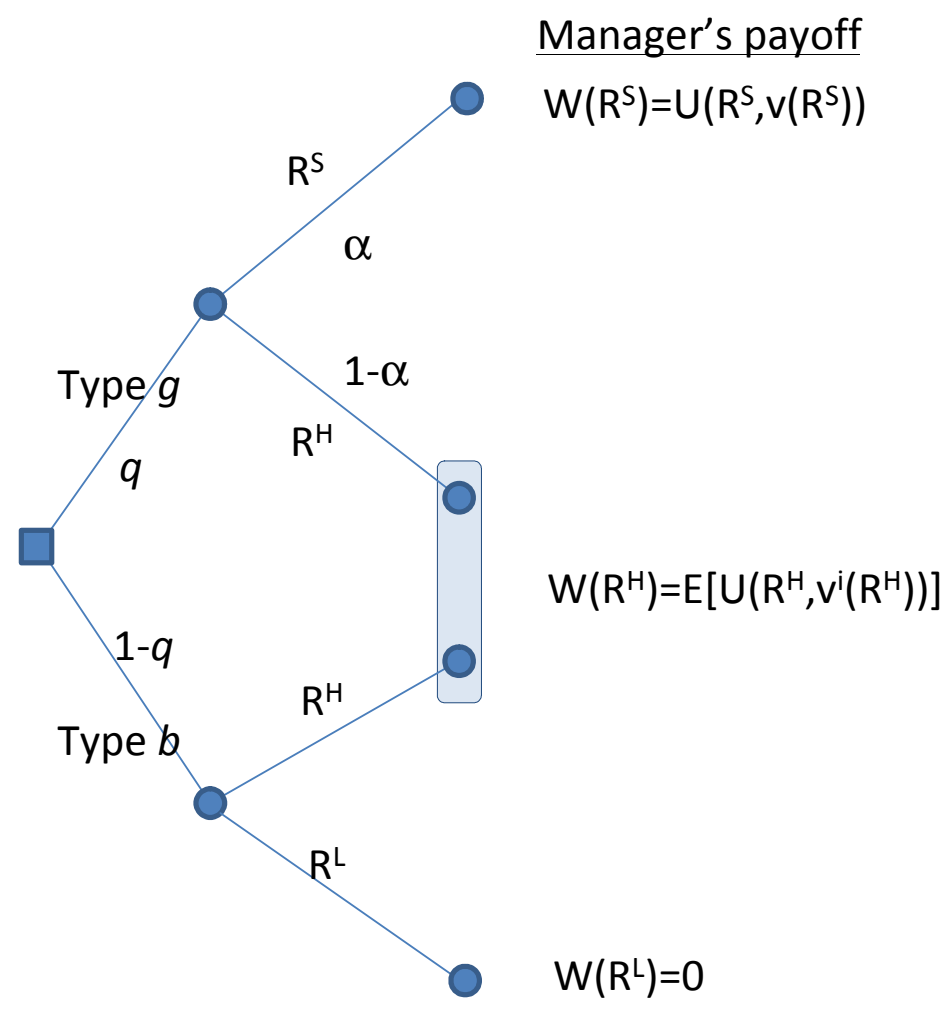

Figure 2: Decision Tree

- At step 0, Nature picks the type of bank, either $b$ or $g$.

- At step 1, depending on their type, banks chose their return strategy.

- At step 2, shareholders make their opinion about the type of bank given the observed returns and pay the manager a compensation proportional to their own expected utility; the game ends.

Finally, we notice that the gap between $U\left(R^{S}, v^{g}\left(R^{S}\right)\right)$ and $U\left(R^{H}, v^{b}\left(R^{H}\right)\right)$ depends on the operating cost $c$. Figure 3 shows that there is a critical $\tilde{c}$ such that $U\left(R^{S}, v^{g}\left(R^{S}\right)\right)=U\left(R^{H}, v^{b}\left(R^{H}\right)\right)$.

Taking $R^{H}$ as given and using Eq. (2), we can show that the utility of the manipulating bad bank is decreasing in $c$ :

$$
\frac{d U\left(R^{H}, v^{b}\left(R^{H}, c\right)\right)}{d c}=\frac{\partial U\left(R^{H}, v^{b}\left(R^{H}, c\right)\right)}{\partial v^{b}\left(R^{H}, c\right)} \frac{d v^{b}\left(R^{H}, c\right)}{d c}=\theta^{-1} U_{v}<0
$$

On the other hand, using Eq. (3) to determine $d R^{S} / d c=-1$ and Eq. (2), to get $d v^{g}\left(R^{S}\right) / d R^{S}=$ $\theta^{-1}$ we can show that the utility of the good bank that implements the signaling strategy is 


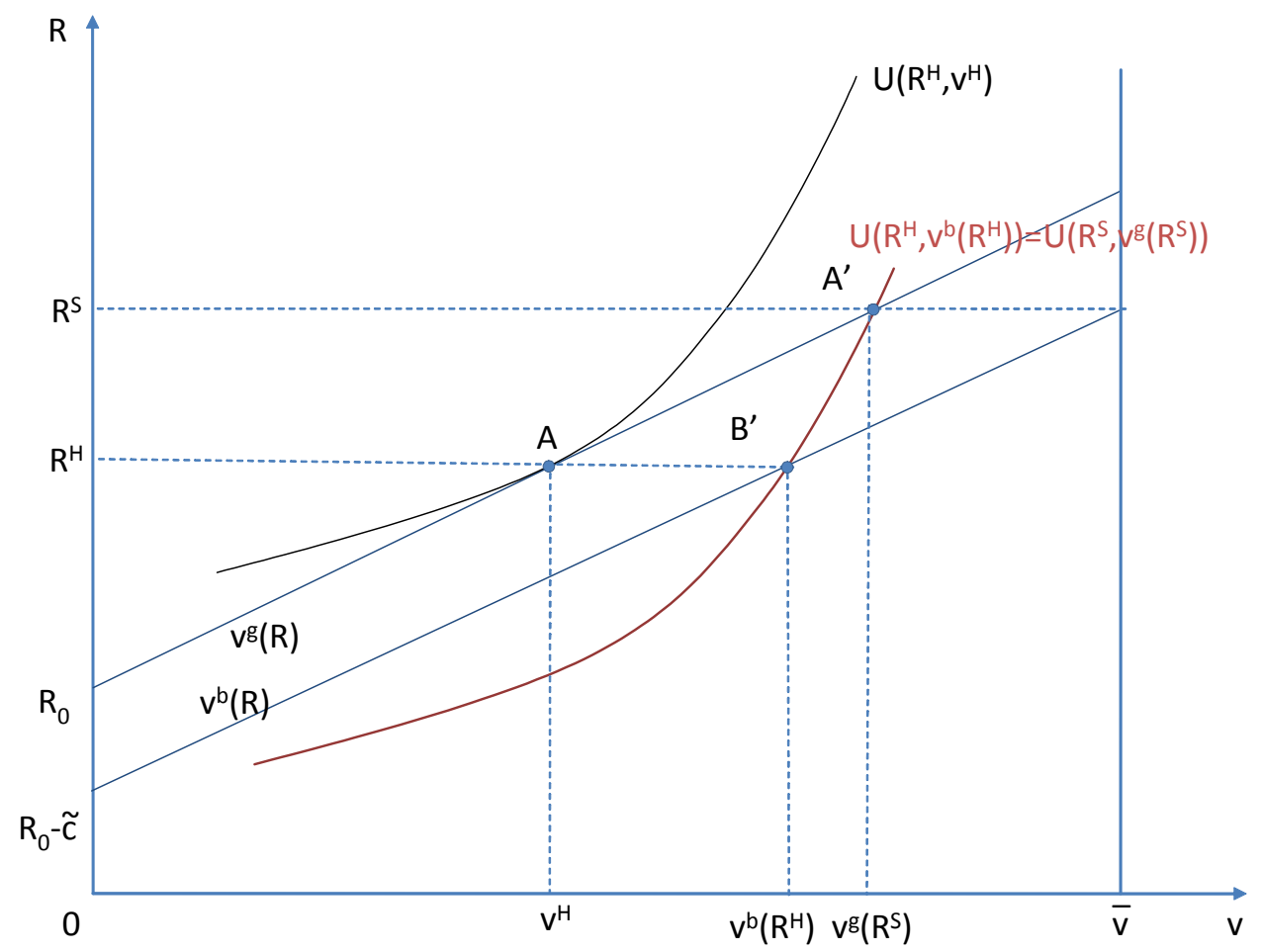

Figure 3: The critical operating cost $\tilde{c}$

increasing in $c$ :

$$
\begin{aligned}
\frac{d U\left(R^{S}(c), v^{g}\left(R^{S}(c)\right)\right)}{d c} & =\frac{\partial U()}{\partial R^{S}}\left(\frac{d R^{S}}{d c}\right)+\frac{\partial U()}{\partial v^{g}} \frac{d v^{g}\left(R^{S}(c)\right)}{d R^{S}(c)}\left(\frac{d R^{S}}{d c}\right)= \\
& =-U_{R}-U_{v} \theta^{-1}=-\theta^{-1} U_{R}\left[\theta-M R S\left(R^{S}, v\left(R^{S}\right)\right)\right]
\end{aligned}
$$

Outside the optimum of the good bank, for $R^{S}>R^{H}$, the marginal rate of substitution $M R S=$ $-U_{v} / U_{R}>\theta$, thus the derivative has a positive sign.

Thus, for any $c<\tilde{c}$ we have $U\left(R^{S}, v^{g}\left(R^{S}\right)\right)<U\left(R^{H}, v^{b}\left(R^{H}\right)\right)$ and for $c>\tilde{c}$, we have $U\left(R^{S}, v^{g}\left(R^{S}(c)\right)\right)>U\left(R^{H}, v^{b}\left(R^{H}, c\right)\right)$. This latter case was depicted in Figure 1.

\section{Equilibria}

An equilibrium of this game is defined as a situation where banks' strategies are optimal (i.e., allow to their CEO to earn the highest compensation) given shareholders' beliefs about the type of bank, and shareholders' beliefs are correct given banks' optimal strategies. We may distinguish between a separating equilibrium (where the return strategy of a bank perfectly reveals its type), a 
pooling equilibrium (where all banks implement the same strategy and thus no information about the type of bank can be inferred from the observed return strategy), and a hybrid equilibrium (where banks play a Nash mixed strategy and this strategy carries some but not full information about their type).

In order to rule out a trivial situation, we admit that, by increasing risk enough, bad banks can deliver the perfect information optimal return of the good bank, or, in an equivalent way, that $R^{S}>R^{H}{ }^{9}$ If bad banks cannot copy the strategy of the good banks, only the latter do survive and implement the perfect information strategy $R^{H}$.

\subsection{Signaling equilibrium: good banks do $R^{S}$}

We can show that an elementary separating equilibrium where all good banks deliver their signaling return $R^{S}$ and bad banks have left the market is always possible.

In such an equilibrium, good banks' strategy is $s(g)=R^{S}$. The equilibrium beliefs are: $\operatorname{Pr}\left[g \mid R^{S}\right]=1$, and, given that any bank that pays less than $R^{S}$ should be a bad bank, $\operatorname{Pr}\left[g \mid R^{L}\right]=0$ and $\operatorname{Pr}\left[g \mid R^{H}\right]=0$.

Bad banks can play either $R^{L}$ or $R^{H}$, but given the system of beliefs, the manager's payoff is: $W\left(R^{L}\right)=W\left(R^{H}\right)=0$. There is no incentive for a bad bank to stay in the market. Furthermore, $R^{S}$ is the optimal strategy for the good bank: indeed, the condition $W\left(R^{S}\right)>W\left(R^{H}\right)=0$ is always true.

In this equilibrium, the risk exposure of good banks exceeds the perfect information level, $v^{g}\left(R^{S}\right)>v^{g}\left(R^{H}\right)$. Good banks resort to excessive risk taking as a barrier to entry.

\subsection{Pooling equilibrium: all banks do $R^{H}$}

We can now put forward the existence of a pooling equilibrium where all banks play $R^{H}$ : bad banks play the perfect information optimal strategy of good banks, and good banks decide not to signal themselves by doing $R^{S}$. Banks' single strategy is $s(i)=R^{H}, \forall i \in\{b, g\}$.

Shareholders' equilibrium beliefs can be written: $\operatorname{Pr}\left[g \mid R^{S}\right]=1, \operatorname{Pr}\left[g \mid R^{H}\right]=q$ and $\operatorname{Pr}\left[g \mid R^{L}\right]=0$. Necessary conditions for this equilibrium are: (1) $W\left(R^{H}\right)>W\left(R^{S}\right)$ for the good bank and

\footnotetext{
${ }^{9}$ In turn, this condition is met only if the operating cost is not too big, i.e. if $c<R_{0}+\theta \bar{v}-R^{H}$.
} 
(2) $W\left(R^{H}\right)>W\left(R^{L}\right)=0$ for the bad bank. Since $W\left(R^{S}\right)>0$, the equilibrium exists under the single condition $W\left(R^{H}\right)>W\left(R^{S}\right)$. Given the definition of the manager's payoff (Eq. 4), this condition becomes:

$$
q U\left(R^{H}, v^{g}\left(R^{H}\right)\right)+(1-q) U\left(R^{H}, v^{b}\left(R^{H}\right)\right)>U\left(R^{S}, v^{g}\left(R^{S}\right)\right)
$$

or:

$$
q>q_{1} \equiv \frac{U\left(R^{S}, v^{g}\left(R^{S}\right)\right)-U\left(R^{H}, v^{b}\left(R^{H}\right)\right)}{U\left(R^{H}, v^{g}\left(R^{H}\right)\right)-U\left(R^{H}, v^{b}\left(R^{H}\right)\right)} .
$$

In the small operating cost case $(c<\tilde{c})$, we have $U\left(R^{S}, v^{g}\left(R^{S}\right)\right)<U\left(R^{H}, v^{b}\left(R^{H}\right)\right)$ that implies $q_{1}<0$ : the previous condition is always true. The pooling equilibrium always exists if the loss of utility of shareholders who support a bad bank is not too large; this can happen if the operating cost gap $c$ is small.

In the large operating cost case $(c>\tilde{c})$, we have $U\left(R^{S}, v^{g}\left(R^{S}\right)\right)>U\left(R^{H}, v^{b}\left(R^{H}\right)\right)$, thus $q_{1}>0$. Furthermore, $q_{1}<1$ as $U\left(R^{S}, v^{g}\left(R^{S}\right)\right)<U\left(R^{H}, v^{g}\left(R^{H}\right)\right)$. We can conclude that in the large cost case, the pooling equilibrium exists only if the frequency of good banks is large enough. If there are not too many bad banks who imitate the good banks, the manager of the latter has not too much to lose, and it does not worth for him to implement an expensive signaling strategy.

In the pooling equilibrium, bad banks take too much risks as compared to the perfect information set-up, but they all survive in this environment.

\subsection{Hybrid equilibrium: some good banks signal themselves, all others play $R^{H}$}

In this equilibrium, a proportion $\alpha$ of the good banks decide to signal themselves by playing $R^{S}$, and $(1-\alpha)$ play their perfect information strategy $R^{H}$. All bad banks copy the latter and play $R^{H}$.

The mixed equilibrium strategy of the good banks is $s(g)=\left\{\alpha R^{S}+(1-\alpha) R^{H} \mid \alpha \in[0,1]\right\}$ and the bad banks' strategy is $s(b)=R^{H}$. Using Bayes rule, and denoting by $\operatorname{Pr}\left[R^{j} \mid i\right]$ the probability that a bank of type $i$ plays strategy $R^{j}$, equilibrium beliefs can be written: $\operatorname{Pr}\left[g \mid R^{L}\right]=0$, $\operatorname{Pr}\left[g \mid R^{S}\right]=1$ and:

$$
\operatorname{Pr}\left[g \mid R^{H}\right]=\frac{\operatorname{Pr}\left[R^{H} \mid g\right] \operatorname{Pr}[g]}{\operatorname{Pr}\left[R^{H}\right]}=\frac{(1-\alpha) q}{(1-\alpha) q+(1-q)}
$$


In equilibrium, a good bank must be indifferent between strategies $R^{H}$ and $R^{S}$ :

$$
W\left(R^{S}\right)=W\left(R^{H}\right) \Leftrightarrow U\left(R^{S}, v^{g}\left(R^{S}\right)\right)=\operatorname{Pr}\left[g \mid R^{H}\right] U\left(R^{H}, v^{g}\left(R^{H}\right)\right)+\operatorname{Pr}\left[b \mid R^{H}\right] U\left(R^{H}, v^{b}\left(R^{H}\right)\right) .
$$

This equation allows us to determine $(1-\alpha)$ with respect to predetermined variables:

$$
(1-\alpha)=\frac{(1-q)}{q} \frac{\left[U\left(R^{S}, v^{g}\left(R^{S}\right)\right)-U\left(R^{H}, v^{b}\left(R^{H}\right)\right)\right]}{\left[U\left(R^{H}, v^{g}\left(R^{H}\right)\right)-U\left(R^{S}, v^{g}\left(R^{S}\right)\right)\right]} .
$$

We first notice that $U\left(R^{H}, v^{g}\left(R^{H}\right)\right)-U\left(R^{S}, v^{g}\left(R^{S}\right)\right)>0$. Hence, in the small cost case $(c<\tilde{c})$, since $U\left(R^{S}, v^{g}\left(R^{S}\right)\right)<U\left(R^{H}, v^{b}\left(R^{H}\right)\right)$ we have $(1-\alpha)<0$ : the hybrid equilibrium is impossible.

In the large cost case $(c>\tilde{c})$, we have $U\left(R^{S}, v^{g}\left(R^{S}\right)\right)>U\left(R^{H}, v^{b}\left(R^{H}\right)\right)$, so $1-\alpha>0$. The equilibrium exists if $1-\alpha<1$, which is equivalent to:

$$
q>q_{1} \equiv \frac{U\left(R^{S}, v^{g}\left(R^{S}\right)\right)-U\left(R^{H}, v^{b}\left(R^{H}\right)\right)}{U\left(R^{H}, v^{g}\left(R^{H}\right)\right)-U\left(R^{H}, v^{b}\left(R^{H}\right)\right)} .
$$

This is the same existence condition as that of the pooling equilibrium in the same large cost case (Eq 8).

In the hybrid equilibrium, both bad banks and a fraction $\alpha$ of the good banks are taking an excessive risk. The maximum amount of risk in the economy appears for $\alpha \rightarrow 1$; we infer that if the hybrid equilibrium is in place, the amount of risk in this economy reaches its highest level for $c \searrow \tilde{c}$.

\subsection{A summary of possible equilibria}

Table 1 presents a summary of the possible equilibria. Except for the case of large costs and a small proportion of bad banks $\left(q<q_{1}\right)$, the game features a typical configuration of multiple equilibria, where the equilibrium that will actually materialize depends on investors' beliefs.

\begin{tabular}{|l|l|l|}
\hline & "Small" cost $(c<\tilde{c})$ & "Large" cost $(c>\tilde{c})$ \\
\hline "A few" bad banks: $q<q_{1}$ & Separating, Pooling & Separating \\
\hline "Many" bad banks: $q>q_{1}$ & Separating, Pooling & Separating, Pooling, Hybrid \\
\hline
\end{tabular}

Table 1. Summary of possible equilibria 
This analysis was performed using general forms for shareholder utility functions. There is no need to argue much about the modelling benefit of general forms as compared with specific forms. The reverse side of the coin is that in absence of explicit forms for our critical thresholds $q_{1}$ and $\tilde{c}$, it is not easy identify what type of equilibrium would describe the best the banking sector situation in the eve of the crisis. If we consider the overall number of banks in the US and Europe (more than 8000 in the US and about 7500 in Europe), the proportion of "bad" banks can be seen as being small. However, if we limit our analysis to the "exclusive" segment of large, multi-product banks with a global reach, then the proportion of banks that were deeply affected by the crisis turned out to be substantial. In general, differences between these large banks in terms of investment opportunities and operating costs are small. Our analysis does not allow to say "how small is small" as compared to the critical cost $\tilde{c}$ (for which we provide only an implicit definition). Thus, on a pure theoretical ground it is impossible to rule out any of the equilibria, including the hybrid one. In a configuration of multiple equilibria, which one actually materialize depends on shareholders' "sandy" expectations. In any case, the most important result from our general analysis is that in any of the possible equilibria banks take too much risks as compared to the perfect information case.

\section{Conclusion}

According to a broad expert consensus, an abnormal accumulation of risk by banks throughout the world was at the origin of the 2007-2009 recession. The analysis in this paper connects this race for risk to the imperfect information in the banking sector. In a world where returns can be observed but risk cannot, banks running with high operating costs would take more risk only to deliver higher returns and be perceived as highly efficient banks. The latter can signal themselves by further increasing risks well above their perfect information optimal level.

Our analysis was built on a very simple model of bank. The representative bank has been represented as a portfolio manager able to arbitrate between risk and return. Such a simplified approach does not allow to address the important role played by bank capital as a buffer for adverse shocks or for signaling purposes. This was the price to pay for a transparent analysis of 
the various signaling strategies.

The game presents several equilibria, all being characterized by excessive accumulation of risk by banks compared to the ideal, perfect information case. Furthermore, depending on the proportion of less efficient banks and the differential in operating costs, the model presents several multiple equilibria configurations, an economic environment prone to instability.

Policy implications are straightforward. Any reform able to reduce the asymmetry of information between banks' managers and shareholders should eliminate a key reason of the race for risk. Yet there is no miracle solution able to achieve this result spontaneously. If banks' true exposure to risk is hard to assess by outsiders and at least some good banks implement their high-risk signaling strategy, then stronger regulation is needed to cap the maximum amount of risk that banks can take. Yet, from a theoretical perspective, what regulation would allow to reach this target is not a settled issue. As already mentioned, the Basel Committee on Banking Supervision decided on September 12, 2010 to gradually rise the minimum requirement for common equity, from $2 \%$ before the crisis, to $7 \%$ by 2019 . It still has to be seen whether such a measures goes in the right direction.

\section{References}

Berger, A. N. and DeYoung R., (1997). Problem loans and cost efficiency in commercial banks, Journal of Banking and Finance, 21, pp. 849-870.

Borio, C., (2008). The financial turmoil of the 2007-?: A preliminary assessment and some policy considerations, BIS Working Paper 251.

Brunnermeier, M. M., (2009). Deciphering the liquidity and credit crunch 2007-2008, Journal of Economic Perspectives, 23, 1, pp. 77-100.

Boot, A. and Marinc, M., (2006). Competition and entry in banking: Implications for stability and capital regulation, Tinbergen Institute Discussion Paper TI 2006-015/2, January 22 .

DeYoung, Robert, (1997). X-efficiency and management quality in national banks, Journal of Financial Services Research, 13, 1, pp. 5-22.

Diamond, D. W. and Raghumaram G. R., (2009). The credit crisis: Conjectures about causes and remedies, American Economic Review: Papers and Proceedings, 99, 2, 606-610.

Haslem, J. A., Scheraga C. A. and Bedingfield, J. P., (1999). DEA efficiency profiles of US banks operating internationally, International Review of Economics and Finance, 8, pp. $165-182$. 
IMF, (2010). World Economic Outlook, International Monetary Fund, Washington DC, April.

Kahane, Y., (1977). Capital adequacy and the regulation of financial intermediaries, Journal of Banking and Finance, 1, pp. 207-218.

Koehn, M. and Santomero A., (1980). Regulation of bank capital and portfolio risk, Journal of Finance, 35, pp. 1235-1233.

Markowitz, H. M., (1952). Portfolio selection, Journal of Finance, 7, pp. 77-91.

Morgan, D. P., (2002). Risk and uncertainty in an opaque industry, American Economic Review, 92, 4, pp. 874-888.

Pomfret, R., (2010). The financial sector and the future of capitalism, Economic Systems, 34 , pp. 22-37.

Spence, M., (1973). Job market signaling, Quarterly Journal of Economics, 87, 3, pp. 355374.

Spence, M., (2002). Signaling in retrospect and the informational structure of markets, Nobel Prize Lecture, American Economic Review, 92, 3, pp. 434-459.

Stiglitz, J. E., (2010). Freefall. Free Markets and the Sinking of the Global Economy, Allen Lane, UK.

Riley, J. G., (1975). Competitive signalling. Journal of Economic Theory, 10, pp. 174-186.

Trichet, J-C., (2008). Réflexions sur les turbulences financières, Intervention auprès de l'Institut Montaigne le 23/12/2008, Paris.

VanHoose, D., (2007). Theories of bank behavior under capital regulation, Journal of Banking and Finance, 31, pp. 3680-3697. 